\title{
VALIDITY OF ANTI-NEGRO RESTRICTIVE COVE- NANTS: A RECONSIDERATION OF THE PROBLEM
}

\author{
Harold I. KAHEN*
}

LMOST two decades have passed since the Supreme Court, in
Corrigan v. Buckley rejected arguments that anti-Negro restric-
tive covenants are unconstitutional, and affirmed the enforcement by injunction of private agreements prohibiting the occupancy of real property by Negroes. In the meantime, the problem of Negro housing in cities, already aggravated by the general tendency toward urbanization and the influx of Negroes into cities to take jobs created by World War I, has again been intensified by the attraction of urban employment opportunities which has characterized the present war. The result has been that, to a much greater extent than is the case with the population in general, Negro housing is inadequate, both qualitatively and quantitatively to meet the minimum requirements which an enlightened social policy would seem to impose. The social problems have reached a boiling point at a time when the current of Supreme Court decision seems to be flowing in a direction favorable to constitutional protection against what were once considered merely infractions of civil rights, or at any rate infractions irremediable in the federal courts. This is the justification for a reexamination, ${ }^{2}$ at the present time, of the constitutional and policy problems involved in the judicial enforcement, by injunction, of private agreements prohibiting the alienation of real property to Negroes or its occupancy by Negroes, ${ }^{3}$ where such a disposition is desired by the owner of the present interest in the land.

* Of the Illinois Bar, and now in the Army of the United States. The writer is greatly indebted to Prof. Sheldon Tefft, of the Law School, University of Chicago, for his active encouragement and numerous helpful suggestions in the writing of this article.

I 27 I U.S. 323,46 S. Ct. 52r, 70 L. Ed. 969 (1926).

* An excellent discussion of the general subject will be found in Martin, Segregation of Residences of Negroes, 32 Mich. L. Rev. 721 (I934), where the legal problem is considered in its sociological setting. Also of interest are Mangum, The Legal Status of the Negro I38-62 (I940); Miller, Race Restrictions on the Use or Sale of Real Property, 2 Natl. B. J. 24 (I944); Bowman, The Constitution and Common Law Restraints on Alienation, 8 Boston U. L. Rev. I (I928); Bruce, Racial Zoning by Private Contract in the Light of the Constitutions and the Rule against Restraints on Alienation, 2x Ill. L. Rev. 704 (1927).

3 Anti-Negro restrictions are generally framed as agreements, breach of which would justify a suit for an injunction or an action for damages. However, covenants framed to con- 
The earliest American case in which a court considered constitutional problems in connection with the enforcement of restrictions on the sale or occupancy of land by members of a particular racial group seems to be Gandolfo v. Hartman. ${ }^{4}$ In that case the deed under which the plaintiff took title to the land involved in the litigation contained an agreement that the premises were never to be rented to a "Chinaman." The plaintiff having conveyed a part of the property to the defendant, suit was brought by the former to enjoin the latter from renting to "Chinamen," who were also made parties defendant. In refusing relief, the court referred to the equal protection clause of the Fourteenth Amendment and, having noted that this clause applies to courts as well as to legislatures, stated that:

It would be a very narrow construction of the constitutional amendment in question, and of the decisions based upon it, and a very restricted application of the broad principles upon which both the amendment and the decisions proceed, to hold that, while state and municipal legislatures are forbidden to discriminate against the Chinese in their legislation, a citizen of the state may lawfully do so by contract, which the courts may enforce. Such a view is, I think, entirely inadmissable. Any result inhibited by the constitution can no more be accomplished by contract of individual citizens than by legislation, and the courts should no more enforce the one than the other.

It is noteworthy that this opinion was written almost a decade after the Civil Rights Cases ${ }^{5}$ had established that the Fourteenth Amendment was protection only against governmental action, and not against the activities of individuals in a private capacity. Consequently, it may be assumed that the court considered the judicial enforcement of the restriction to be the crux of the matter, and was not relying on the discrimination expressed in the contract. ${ }^{6}$

In subsequent cases involving restrictive covenants against Negroes the Gandolfo case has generally been overlooked, or, when noticed, it has been distinguished away or disregarded. In the state courts, a line of cases beginning with Queensborough Land Co. v. Cazeaux 7 fails to recognize any

fer a right of entry for condition broken, i.e., to work a forfeiture of the property on breach of the restriction, are not uncommon. Although this discussion is directed primarily towards the usual case, where injunctive relief is sought to prevent or remedy a breach of the restriction, it is believed that the reasoning should apply as well to actions for damages or to enforce a forfeiture.

449 Fed. I8I (Cal., I892). The quotation is from p. 182.

5 rog U.S. 3,3 S. Ct. I8, 27 L. Ed. 835 (I883).

${ }^{6}$ In the latter half of its opinion, the court indicated that enforcement of the covenant would also violate the most-favored-nation clause of a treaty between the United States and China and was contrary to public policy, as well. Gandolfo v. Hartman, 49 Fed. $181-83$ (C.C. CaI. 1892 ).

${ }^{7}$ I36 La. 724,67 So. 64r, I9r6B L.R.A. I20r (I9I5). 
distinction between the application of the Fourteenth Amendment to judicial enforcement of restrictive covenants and its application to the enforcement of such restrictions by the private actions of individuals. The language of the opinions is suggestive that counsel may generally have failed to spell out the constitutional issues, in terms of state action through judicial enforcement, ${ }^{8}$ and have contented themselves, instead, with the argument that the covenants themselves violate constitutional guarantees - a contention which, so put, has long since been foreclosed by the doctrine of the Civil Rights Cases. Hence the tendency has been to brush aside arguments as to constitutionality with little discussion other than the simple statement, as in the Queensborough Land Co. case, that "the Fourteenth Amendment, in so far as prohibiting discrimination against the Negro race, applies only to state legislation, not to the contracts of individuals."

More than thirty years appear to have elapsed after the judgment in the Gandolfo case before the question of the constitutionality of restrictive covenants directed at a particular race was raised again in the federal courts. Corrigan v. Buckley ${ }^{\text {To }}$ was a suit to enjoin one defendant, a white land-owner, from conveying his land to the other defendant, a colored would-be purchaser, in violation of a restrictive covenant against sale or leasing to a colored person. The colored defendant took the position that the covenant was void in that it deprived him of due process of law. Following the state cases, the court rejected his argument on the ground that the civil rights clauses of the Constitution do not apply to private arrangements among individual citizens. On appeal, the Supreme Court held that,

${ }^{8} \mathrm{~A}$ case in which this issue does seem to have been squarely presented is Title Guarantee and Trust Co. v. Garrott, 42 Cal. App. I52 (I9I9), where the court said, at p. I54: "The fourteenth amendment, it is true, applies to the judicial as well as the legislative department of the state government. But the judiciary does not violate this provision of the federal constitution merely because it sanctions discriminations that are the outgrowths of contracts made by individuals."

${ }^{9}{ }_{13} 6$ La. 724, 728, 67 So. 641, 643, IgI6B L.R.A. I20I, I 203 (Igr5). Illustrative cases are: Los Angeles Investment Co. v. Gary, I8I Cal. 680, I86 Pac. 596 (I9rg); Parmalee v. Morris, 2I8 Mich. 625, I88 N.W. 330 (x922); Porter v. Barrett, 233 Mich. 373, 206 N.W. 532, 42 A.L.R. I 267 (x925); Chandler v. Ziegler, 88 Colo. $x, 291$ Pac. 822 (x930); United Cooperative Realty Co. v. Hawkins, 269 Ky. 563, I08 S.W. 2d 507 (r937); Meade v. Dennistone, I73 Md. 295, I96 Atl. 330, II4 A.L.R. I227 (1938). But see Miller v. Jersey Coast Resorts Corp., 98 N.J. Eq. 289, 297, r30 Atl. 824, 828 (r925) to the effect that a restrictive covenant prohibiting members of a particular religious faith from purchasing land would be unconstitutional. However, the opinion cites no authority, nor did the covenant involved in the case contain such a provision, and the injunction was denied on the ground that there had been no breach of the narrow restrictions established.

${ }^{10} 299$ Fed. 899 (C.A.D.C., 1924). 
in view of the Civil Rights Cases and similar decisions, the contention of the colored defendant that the covenant was a denial of rights secured by the Constitution did not raise a constitutional question sufficiently substantial even to support jurisdiction on appeal. In the Supreme Court the contention was also made, apparently for the first time, that the decree of the court enforcing the covenant, as distinguished from the covenant itself, deprived the defendants of their rights under the Fifth and Fourteenth Amendments. Mr. Justice Sanford indicated that that particular question had not properly been presented for review, but he went on to say that, in any event, that contention was likewise without merit. Consequently, the appeal was dismissed for want of jurisdiction. ${ }^{\mathrm{Ix}}$

Although Corrigan v. Buckley has never since been cited by the Supreme Court itself, it has been followed in subsequent cases involving similar restrictions, both in the District of Columbia and in state courts. ${ }^{\mathrm{r2}}$ Only a single court, the Supreme Court of Maryland, appears to have expressed any doubts of its soundness. In Meade v. Dennistone, ${ }^{13}$ this court, although following the Supreme Court rule to uphold the constitutionality of judicial enforcement of an anti-Negro restriction, indicated its own misgivings:

The constitutional question here raised having been thus settled [in Corrigan v. Buckley] by an authority which, unless and until overruled, must be accepted, the only thing for us to decide is whether the agreement before us is adequate to accomplish the purpose intended. .... ${ }^{x}$

Notwithstanding the fact that the decisions enforcing anti-Negro restrictions have been steadily increasing in significance, nothing in the opinions indicates that the social consequences of the rules enunciated have been brought to the attention of the courts. When the Gandolfo case was decided in I892, the Negro population of the country was still almost entirely rural..$^{\mathrm{x}}$ The covenant in that case represented a state of mind which had culminated, a décade earlier, in the enactment of the Chinese Exclu-

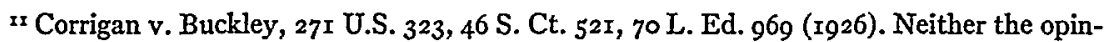
ion in the Court of Appeals nor that in the Supreme Court mentions the Gandolfo case.

I2 Grady v. Garland, 89 F. 2d 8I7 (C.A.D.C., I937); Herb v. Gerstein, 4I F. Supp. 634 (D.C.D.C., I94r); United Cooperative Realty Co. v. Hawkins, 269 Ky. 563, ro8 S.W. 2d 507 (I937).

${ }^{13}$ I 73 Md. 295, 196 Atl. 330, II4 A.L.R. 1227 (1938).

${ }^{4} 173$ Md. 295, 302, I96 Atl. 330, 333, x44 A.L.R. r227, 1232-3 (r938).

15 Of a total Negro population in rgoo of almost 9,000,000, only 2,000,000 lived in cities. T. J. Woofter, Jr., in Recent Social Trends $5^{67}$ ( $\left(x_{933}\right)$.

With respect to segregation in rural areas see Vance, "Racial Competition for Land" in Race Relations and the Race Problem (edited by Edgar T. Thompson) 97, 106 (1939). 
sion Act, ${ }^{16}$ but it is apparent that the draftsman of that particular covenant had not yet come to view Negro occupancy as a problem.

The twentieth century brought Negroes in unprecedented numbers to the cities, especially in the North. ${ }^{17}$ Generally constituting a depressed class, economically, they could hardly have been expected to settle uniformly throughout cities, even in the absence of restrictions. ${ }^{18}$ They showed, instead, a tendency to locate in those sections where housing was cheapest. This has been characteristic of immigrant groups, as well. ${ }^{29}$

In the case of Negroes, however, there soon became evident a desire to exclude from the more desirable neighborhoods even those Negroes who could pay for better accommodations. Based in part on simple prejudice, this desire was reinforced by the fears of property owners, since depreciation of property values is generally assumed to be an inevitable concomitant of Negro occupancy or even proximity. ${ }^{20}$ It expressed itself in legisla-

${ }^{16} 22$ Stat. 58 (I882), 8 U.S.C. $\S 263$.

17 The following tables illustrate the growth of the Negro urban population. Increase in Negro Population of Ten Leading Industrial Cities

\begin{tabular}{|c|c|c|c|c|c|c|c|c|}
\hline \multirow{2}{*}{ CIIY } & \multicolumn{2}{|c|}{ Igro } & \multicolumn{2}{|c|}{ I920 } & \multicolumn{2}{|c|}{ I930 } & \multicolumn{2}{|c|}{1940} \\
\hline & $\begin{array}{l}\text { Number of } \\
\text { Negroes }\end{array}$ & $\begin{array}{l}\text { \% of } \\
\text { Total } \\
\text { Pop. }\end{array}$ & $\begin{array}{l}\text { Number of } \\
\text { Negroes }\end{array}$ & $\begin{array}{l}\text { \% of } \\
\text { Total } \\
\text { Pop. }\end{array}$ & $\begin{array}{l}\text { Number of } \\
\text { Negroes }\end{array}$ & $\begin{array}{l}\text { \%of of } \\
\text { Total } \\
\text { Pop. }\end{array}$ & $\begin{array}{l}\text { Number of } \\
\text { Negroes }\end{array}$ & $\begin{array}{l}\% \text { of } \\
\text { Total } \\
\text { Pop. }\end{array}$ \\
\hline 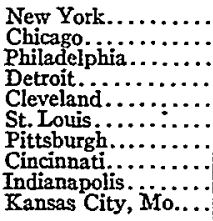 & $\begin{array}{r}91,709 \\
44,103 \\
84,459 \\
5,741 \\
8,448 \\
43,960 \\
25,623 \\
19,639 \\
21,816 \\
23,556\end{array}$ & $\begin{array}{l}I .9 \\
2.0 \\
5.5 \\
I .2 \\
1.5 \\
6.4 \\
4.7 \\
5.1 \\
9.3 \\
9.5\end{array}$ & $\begin{array}{r}152,467 \\
109,458 \\
134,229 \\
40,838 \\
34,451 \\
69,854 \\
37,725 \\
30,079 \\
34,678 \\
30,719\end{array}$ & $\begin{array}{r}2.7 \\
4.1 \\
7.4 \\
4.1 \\
4.3 \\
9.0 \\
6.4 \\
7.5 \\
11.0 \\
9.5\end{array}$ & $\begin{array}{r}327,706 \\
233,903 \\
219,599 \\
120,066 \\
71,899 \\
93,580 \\
54,983 \\
47,818 \\
43,967 \\
38,574\end{array}$ & $\begin{array}{r}4.7 \\
6.9 \\
11.3 \\
7.7 \\
8.0 \\
11.4 \\
8.2 \\
10.6 \\
12.1 \\
9.8\end{array}$ & $\begin{array}{r}458,444 \\
277,731 \\
250,880 \\
149,119 \\
84,504 \\
108,765 \\
62,216 \\
55,593 \\
51,142 \\
41,574\end{array}$ & $\begin{array}{r}6.1 \\
8.2 \\
13.0 \\
9.2 \\
9.6 \\
13.3 \\
9.3 \\
12.2 \\
13.2 \\
10.4\end{array}$ \\
\hline
\end{tabular}

Increase in Negro Urban Population

\begin{tabular}{|c|c|c|c|c|}
\hline & I9IO & 1920 & 1930 & r940 \\
\hline 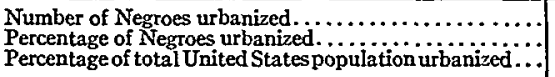 & $\begin{array}{l}2,684,797 \\
27.3 \\
45.8\end{array}$ & $\begin{array}{l}3,559,473 \\
34.0 \\
51.4\end{array}$ & $\begin{array}{l}5,193,913 \\
43.7 \\
56.2\end{array}$ & $\begin{array}{l}6,253,588 \\
48.6 \\
56.5\end{array}$ \\
\hline
\end{tabular}

Source: United States Census.

See chapter $\Pi$, The Rapid City Growth, in Woofter, Negro Problems in Cities 26-36 (I928).

${ }^{28}$ For a discussion of the patterns of Negro settlement in cities, see ibid., 37-77.

${ }^{9}$ Report on Negro Housing of the President's Conference on Home Building and Home Ownership 5 ( $\mathrm{r}_{932}$ ).

${ }^{20}$ The popular view that Negro "invasion" of an area necessarily depreciates property values is not shared by all writers who have investigated the subject. The better view seems to be that depreciation of property in such areas is temporary, due to sacrifice sales by white owners in their haste to leave the area. When the property has been largely taken over by 
tion, ${ }^{2 x}$ especially municipal ordinances, segregating Negroes and in restrictive covenants.

Buchanan v. Warley, ${ }^{22}$ the first case in the Supreme Court to hold one of these segregation ordinances unconstitutional, was not completely successful in discouraging their subsequent enactment. As late as I940, the North Carolina Supreme Court was required to hold a segregation ordinance unconstitutional. ${ }^{23}$ But, as real estate brokers and local improvement associations have come to recognize the futility of promoting this purpose by legislation, the restrictive covenant has been preferred as a method of excluding Negroes from desirable neighborhoods.

Restrictive covenants covering wide areas, and enforced by injunction, are capable of imposing much more drastic restraints than are segregation ordinances patterned upon zoning ordinances. Moreover, whereas zoning ordinances may be readily modified to conform with changes in political, economic, and social conditions, well-drafted restrictions are likely to be impregnable for an indefinite period. ${ }^{24}$ Indeed, the very inflexibility of such covenants, initially, in preventing an influx of Negroes into a neighborhood has redounded to the detriment of property owners subsequently in cases where changed conditions have made a good proportion of the property in the neighborhood disposable advantageously only to colored persons. ${ }^{25}$

No exact figures seem to have been compiled to show the extent to which residential property in cities is covered by covenants prohibiting

Negroes, and sacrifice sales have ceased, values appear to return to normal, unless other factors intervene. See Report of the Chicago Commission on Race Relations, The Negro in Chicago 194-215 (1922), for a discussion of such factors.

${ }^{2 x}$ The evolution of such legislation is traced in Charles S. Johnson, Patterns of Negro Segregation ${ }_{173^{-6}}$ (1943).

$2 z 245$ U.S. 6o, 38 S. Ct. $x 6,62$ L. Ed. $x 49$ (1917).

${ }_{23}$ Clinard v. Winston-Salem, 217 N.C. rrg, 6 S.E. $2 d 867$ (1940).

${ }^{24}$ Among the theories which have occasionally been utilized to deny enforcement to restrictive covenants are (I) that conditions have changed (see note, Negro Restrictions and the "Changed Conditions" Doctrine, 7 Univ. Chi. L. Rev. 7 I0 [1940]), (2) that the covenants constitute illegal restraints on alienation (see Bowman, op. cit. supra, note 2), (3) that the plaintiff has acquiesced in similar violations, (4) that restrictions were not uniformly imposed originally and hence it is inequitable to bind $A$, where $B$, his neighbor, is free to use the property for a similar purpose. The results have varied in different jurisdictions and even in the same jurisdiction. See note to Kathan v. Stevenson, 307 Mich. 485, I2 N.W. 2d $33^{2}$ (I943) in 42 Mich. L. Rev. 923 (1944), and 3 Tiffany, Real Property $\$ \$ 871-5$ (3d ed. r939).

${ }^{25}$ Grady v. Garland, 89 F. 2d 817 (C.A.D.C., 1937) was a suit by white property owners, whose houses were on the border of a restricted area and faced property occupied by Negroes, to remove the restrictions as a cloud upon their title. Relief was denied on the ground that a change of conditions in an adjoining neighborhood was immaterial so long as there had been no such change with respect to the property covered by restrictions. 
alienation to or occupancy by Negroes. However, there appears to be an increasing tendency toward the use of such covenants, ${ }^{26}$ and it can hardly be questioned that a substantial proportion of urban residential property is already affected. ${ }^{27}$ No less significant than the absolute amount of restricted property, or its proportion to the entire residential property in a community, may be the location of the restricted property with relation to established areas of Negro settlement. Restrictions covering a relatively small amount of property may effectively constrict the area of Negro settlement, if the restricted property substantially surrounds the Negropopulated area, or stands as a barrier to expansion in the only direction toward which expansion is feasible.

Covenants on improved property are often sponsored by local improvement associations, ${ }^{28}$ which bring pressure upon householders to join with their neighbors in imposing restrictions upon every piece of property in a neighborhood, without exception. Not every such solicitation can be successful, ${ }^{29}$ and, unless the covenants are so drafted as to take effect only if substantial unanimity is secured, those property owners who bind themselves are likely to discover, as time elapses and the neighborhood changes, that they are in an unenviable position..$^{30}$

A more efficient method of imposing restriction throughout a neighborhood is the practice of subdividers to include racial restrictions in the original deed to each lot in a subdivision. Of eighty-four subdivisions con-

${ }^{26}$ Sterner, The Negro's Share $208-9$ (1943). See Report of Pennsylvania State Temporary Commission on the Conditions of the Urban Colored Population I3I ff. (1943).

${ }^{27}$ An "estimate" that as much as 80 per cent of the residential property in Chicago is covered by anti-Negro restrictions is given in "Iron Ring in Housing," 47 The Crisis 205 (1940), quoted in I Myrdal, An American Dilemma 624 (I944). Though this figure seems too high for credence, even if it includes informal agreements as well as formal written restrictions, it is often quoted and no better one seems to be available. The "estimate" was the impression of Robert Taylor, Chairman of the Chicago Housing Authority, but was based on no survey. In a recent speech Newton C. Farr, former president of the Chicago Real Estate Board, stated that in his opinion less than 40 per cent of the area was covered.

${ }^{28}$ There are said to be 175 such organizations in Chicago alone. Embree, Brown Americans 34 (1943).

${ }^{29}$ In the Washington Park Subdivision of Chicago, the covenant which gave rise to the litigation in Hansberry v. Lee, 3 II U.S. 32,6 I S.Ct. II5, 85 L. Ed. 22 (I940) was so drafted as to be enforceable only if the owners of 95 per cent of the frontage signed. In fact, the owners of no more than 54 per cent of the frontage signed.

${ }^{30}$ This was precisely the situation of the signers of the Washington Park Subdivision covenant, after the Supreme Court of Illinois had held in Lee v. Hansberry, 372 Ill. 369,24 N.E. 2d 37 (r939) that Burke v. Kleiman, 277 Ill. App. 5I9 (I934) had conclusively established that that covenant was operative. The signers could not dispose of their property to Negroes, although in many cases their neighbors had already made such a disposition.

See William Henry Jones, The Housing of Negroes in Washington, D.C. 72-4 (1929) for a discussion of similar occurrences. 
sidered in a study made some years ago, it was found that racial restrictions were imposed in forty, of which thirty-eight were in the more recent instruments. ${ }^{31}$ The Manual on Land Subdivision published by the American Society of Civil Engineers ${ }^{32}$ states:

Restrictive covenants in deeds specifying the exact use of the property, the side, rear, and front yards, the cost of the house, the architecture, and even the race of the inhabitants, are extremely useful in design. They should be outlined at the time the design is made. The judicious use of restrictive covenants will do much to establish and protect property values. Such covenants are valuable in all residential developments; subdivisions for the poor, as well as for those of more ample means, benefit from such controls. ${ }^{33}$

Following the commercial trend, the governmęnt agency which is concerned with the extension of credit for the construction and improvement of private housing for low income groups appears to have promoted similar restrictions. "The Federal Housing Administration, in effect, extends credit to Negroes only if they build or buy in Negro neighborhoods and to whites only if they build in white areas which are under covenant not to rent or sell to Negroes." 34 However, the United States Housing Authority, which develops public housing on a large scale, appears to have followed a somewhat different policy. ${ }^{35}$

Caught between increasing population pressure from within and restric-

${ }^{3 x}$ Monchow, The Use of Deed Restrictions in Subdivision Development 50 (r928).

${ }^{32}$ In 1939.

33 Am. Soc. of Civil Engineers, Manual on Land Subdivision 23 (1939). Italics added. There follows a set of restrictions which are said to have been suggested by the Federal Housing Administration. Included among them is the following: "No race or nationality other than those for whom the premises are intended, shall use or occupy any building on any lot, except that this covenant shall not prevent occupancy by domestic servants of a different race or nationality employed by an owner or tenant. (The wording of this restriction should not be used in actual restrictions which are to be recorded, but a racial restriction should be properly drawn so that the objectives as above set forth will be acccomplished.)" Ibid.

34 I Myrdal, An American Dilemma 625 (r944). See also id., 349-50 and Sterner, The Negro's Share $3^{\text {I }} 4^{-16}$ (I943). The writer is informed, however, that FHA policy in respect to restrictive covenants is not determined centrally but by state administrators in the light of local conditions.

35 "The United States Housing Authority .... has attempted to prevent the spread of residential segregation by encouraging occupancy of public housing projects by both whites and Negroes, especially in neighborhoods where mixed occupancy was the rule prior to construction of the public project." Putney, Civil and Social Rights of the Negro, I Editorial Research Reports 2II, 228 (I939). But this policy seems to have yielded to the pressure of local opinion on numerous occasions, and its success appears to have been spotty. See Sterner, The Negro's Share 320 (1943).

Favors v. Randall, $40 \mathrm{~F}$. Supp. $743(\mathrm{~Pa}$., I94I), presented the question whether the policy of a local affiliate of the Authority, to rent to Negroes in a ratio based on the proportion of Negro occupancy of the site prior to construction of the project, was discrimination in contravention of the Fourteenth Amendment. The court found that the discrimination was reasonable and refused relief. 
tive covenants binding from without, Negro housing conditions have shown a steady tendency toward deterioration, especially when compared with the general trend. Dilapidation, congestion, ${ }^{36}$ and lack of sanitation are common. ${ }^{37}$ Lack of space for expansion has tended, moreover, to promote monopoly conditions within Negro areas, making it possible to collect high rentals for the most dilapidated property..$^{8}$ This in turn has necessitated the taking in of lodgers to meet rent payments, with all of the social evils incident to this practice. The social cost of such slum conditions in terms of lowering of the standards of public health, juvenile delinquency, crime, and other forms of social disorganization is inestimable. ${ }^{39}$ The discontent which has been aroused by such conditions has been recognized as a potentially explosive element in an already highly volatile social situation. ${ }^{40}$

Although it is clear that even in the absence of restrictive convenants other social factors would operate to prevent the penetration of Negroes into certain residential districts, ${ }^{4}{ }^{4}$ it is accepted that the covenants are a

${ }_{36}^{6}$ "In a single block in Harlem there are $3,87 x$ people. Comparable concentration for the entire population would result in all of the people of the United States living in one half of New York City." Embree, Brown Americans 34 (r943).

"Mllustrating the plight of Chicago's Negro population, Ferd Kramer, president of the Metropolitan Housing Council, said about 300,000 Negroes now live in accommodations ' $w$ hich normally would house only one-third that number. ....'

"Kramer said the huge war time increase of Chicago's Negro population, at a rate of 25,000 to 30,000 a year, has been unaccompanied by expansion of housing facilities." Chicago Sun, Nov. 29, r944. (final ed.) p. 7, col. 3-6.

37 Report on Negro Housing, op. cit. supra, note I9; Sterner, The Negro's Share $166-209$ (I943); $x$ Myrdal, An American Dilemma 375-9 (I944); Report of Pennsylvania State Temporary Commission, op. cit. supra, note $26,7 \mathrm{I}-169$. A detailed description of the Negro housing situation in Chicago, at the present time, appears in a series of articles published in the Chi-. cago Sun, beginning Jan. 8, 1945.

${ }^{38}$ Headley, "Rent," chap. VII in Woofter, Negro Problems in Cities I2I-35 (I928). While the near-monopoly position of landlords owning Negro-occupied property makes ordinary maintenance unnecessary, the artificial increase of property values due to high rentals required of Negroes also tends to prevent the removal of obsolete property and its replacement by construction which would utilize the land to the best economic advantage.

39 Report of Pennsylvania State Temporary Commission, op. cit. supra, note 26, I39-42, 147-53, Report on Negro Housing, op. cit. supra, note 19 , I43-98. For a general discussion of the significance of segregation see Wirth, Segregation, 7 Ency. Soc. Sci. 643 (r937) and Sterner, The Negro's Share 200-2 (1943).

40 "In Chicago, the lack of housing facilities has caused an aggravation of discontent which students have warned is approaching a crisis. The iron ring of restrictive covenants which surrounds the Negro community has prevented its normal expansion in spite of the fact that the colored population has more than doubled in the last two decades. ...." "Iron Ring in Housing," 47 The Crisis 205 (I940).

${ }^{4}$ Among these factors are the tendency to charge Negroes higher rents than white persons for property outside the "Black Belt," the tendency of landlords to refuse to rent to Negroes, even in the absence of formal restrictions, and the financial inability of most Negroes to pay 
principal factor in segregating the Negro population of cities in small areas and denying to Negroes the opportunity to reside elsewhere. ${ }^{42}$ The practical consequences of such segregation in terms of reduced standards of living have already been noted. It follows that judicial enforcement of antiNegro restrictions amounts substantially to a denial to Negroes of the right to a reasonable choice of adequate home-sites in the community. Once this is recognized, the legal doctrines precluding enforcement become more apparent.

If the litigation of constitutional issues and issues of land policy in a sociological vacuum has resulted in socially undesirable doctrines, it would seem appropriate, in any litigation which may hereafter be undertaken, to include the relevant sociological data in the record and briefs. No court should be called upon to determine the validity of an anti-Negro restrictive covenant on the tacit assumption that only the parties litigant and the parcel of land as to which they assert rights will be affected by the decision. Instead, the relationship of the particular restriction to the entire community should clearly appear. A general indication of the type of sociological material which may be drawn upon has already been given.

In presenting a case involving the validity of a particular restriction, a study should be made of the extent to which land in the adjacent community is affected by anti-Negro restrictions. The facts may be obtainable from local title companies, from real estate brokers, or from published handbooks on local real estate. The most accurate and complete sources, of course, are in the books maintained by the local recorders of titles, but this method of research appears to be unduly laborious, if the facts can be otherwise discovered. Further proof may then be adduced by assembling the census figures on the increase of the local Negro population and compar-

for housing in expensive neighborhoods. There is also the desire on the part of many Negroes to remain in areas where they are socially acceptable, even if the physical surroundings are undesirable, and the correlative desire to avoid being subjected (if they move to a predominantly white neighborhood) to daily contact with ofttimes bitterly hostile neighbors. The report of the Chicago Commission, op. cit. supra, note 20, a study of the race riots in Chicago in I9r9, while it devotes some 125 pages (106-230) to the distribution of the Negro population and to its housing problem, and discusses in some detail the methods used by property owners to prevent Negro infiltration into white areas, does not seem to mention restrictive covenants as a factor in segregation. Apparently such covenants had not become popular in Chicago prior to the increase in Negro population which resulted from World War I.

$4^{2}$ "In Washington, the 'covenant' seems to be the most widely employed method for keeping Negroes out of 'exclusively white' residential districts." Jones, op. cit. supra, note 30 , p. 7 .

"If the [Supreme] Court should follow up its action of declaring all local laws to segregate Negroes unconstitutional by declaring illegal also the private restrictive covenants, segregation in the North would be nearly doomed, and segregation in the South would be set back slightly." I Myrdal, An American Dilemma 624 (I944). 
ing this increase with the expansion of the local areas of Negro settlement. If the areas of Negro habitation in the locality have not increased in proportion to population increases, and the density of the local Negro population has been increasing at a greater rate than that of the white population, there is evidence of the effect of the restrictions. Still more cogent evidence might be adduced by plotting on a map of the city the areas of Negro habitation at various times in the past, the direction in which expansion of the Negro settlement has moved, and the areas in which restrictive covenants have been imposed. A tendency for Negroes to move toward the restricted area but to stop at its boundaries is evidence that the covenants are a principal factor in denying to Negroes the right to live where they desire. ${ }^{43}$

The consequences of such segregation should also be shown. Published studies of the Negro housing situation are available for many large cities ${ }^{44}$ and should disclose such items as the physical condition of housing, the extent of overcrowding, and the rent level as compared with housing available to white persons. Expert testimony may also be avallable in a particular case.

If, as has been suggested, it can be shown that the tendency and effect of the enforcement of anti-Negro restrictive covenants in a particular community is substantially to deny to Negroes, who are otherwise capable of paying for better housing facilities, the opportunity of securing reasonably adequate housing, refusal to enforce such covenants would appear to be in keeping with the best traditions of courts of equity. That it is not every covenant with respect to land which will be specifically enforced in equity is well settled..$^{45}$ Even in the limited field of racial cove-

43 Illustrating the techniques which are suggested are the maps in Woofter, Negro Problems in Cities $40-67$ ( $\left.\mathrm{I}_{928}\right)$ and Lindstrom, The Negro Invasion of the Washington Park Subdivision 8, I5, 20, 32 (master's thesis, Univ. Chi. I94r).

44 Examples of such studies are the Report of the Chicago Commission, op. cit. supra, note 20; Jones, op. cit. supra, note 30; Report of the New York State Temporary Commission on the Condition of the Urban Colored Population, N.Y. Legis. Doc. (r938) No. 63, vol. I8, r6 Ist sess.; Report of the Pennsylvania State Temporary Commission, op. cit. supra, note 26 .

${ }_{45}$ In Norcross v. James, I40 Mass. I88, 2 N.E. 946 ( 1885$)$ the court refused to enforce the covenant of a land-owner that he would permit no quarry to be worked on land which he retained, notwithstanding that the covenant had been made on the occasion of the conveyance by such owner of a contiguous tract, which was a quarry of six acres. The language of Holmes, $\mathrm{J}$., is pertinent to the question under consideration:

"The question remains, whether, even if we make the further assumption that the covenant was valid as a contract between the parties, it is of a kind which the law permits to be attached to land in such a sense as to restrict the use of one parcel in all hands for the benefit of whoever may hold the other, whatever the principle invoked. For equity will no more enforce every restriction that can be devised, than the common law will recognize as creating an easement every grant purporting to limit the use of land in favor of other land. The principle 
nants, doctrines limiting enforcement have been recognized. ${ }^{46}$ Basically such doctrines must be founded on conceptions of policy, although terms more specific than "public policy" may be used in stating the results.

The question whether a court of equity will specifically enforce a system of contracts, which operate to prevent an entire race from securing reasonable living accommodations in a community, and effective to accomplish that purpose, is a question which, it is believed, remains open in every jurisdiction. In the cases enforcing anti-Negro restrictions the opinions ordinarily give no indication that the general factual background, which should be a determining factor in the result, was presented for judicial consideration. ${ }^{47}$ Hence the cases in which the restrictions were simply enforced, and

of policy applied to affirmative covenants, applies also to negative ones . . . new and unusual incidents cannot be attached to land by way either of benefit or burden. ....

"Again, this covenant illustrates the further meaning of the rule against unusual incidents. If it is of a nature to be attached to land, as the plaintiff contends, it creates an easement of monopoly, - an easement not to be competed with,- -and in that interest alone a right to prohibit one owner from exercising the usual incidents of property. It is true that a man could accomplish the same results by buying the whole land and regulating production. But it does not follow, because you can do a thing in one way, that you can do it in all; and we think that, if this covenant were regarded as one which bound all subsequent owners of the land to keep its products out of commerce, there would be much greater difficulty in sustaining its validity than if it be treated as merely personal in its burden." 140 Mass. 188, x91-3, 2 N.E. 946, 948-9.

${ }^{6}$ See note 24, supra.

47 Mays v. Burgess, decided Jan. 24, I945, in the Court of Appeals of the District of Columbia, appears to be a notable exception. Nevertheless, the majority of the court was not moved to depart from the rule of the Corrigan case on the basis of the facts presented. Groner, J., writing the opinion of the court, stated that "rights created by [racial] covenants .... have been so consistently enforced by us as to become a rule of property and within the accepted public policy of the District of Columbia. Little need now be said on the subject of that policy. The proposition is not new and was unsuccessfully urged in the Corrigan case . . . in this court and in the Supreme Court. And nothing is suggested now that was not considered then .... public policy.... may not-properly-be found in our personal views on sociological problems." Miller, J., concurred on the ground that the law was established by the decisions, and that, if changes are in order, it is the function of Congress or of the Supreme Court to make them. Edgerton, J., dissenting, contended that "aside from the fact that our Corrigan decision was probably unsound when it was rendered . . . . it is quite inapplicable today because general conditions have not remained the same. Questions of policy have no meaning in a vacuum but relate to particular situations. The housing situation in the District of Columbia has changed since 1924 . . . . The conditions in which many of the 187,000 Negroes in the District of Columbia have long been obliged to live are now worse than ever."

In California, where there has been relatively much litigation involving restrictive covenants, recent opinions also indicate that counsel may have begun to present factual background material to the courts. It has been received with varying degrees of enthusiasm.

In Fairchild v. Raines, I5I P. 2d 260, 267 (Cal., I944), Traynor, J., concurring in the reversal of a judgment enforcing a restrictive covenant, summarized relevant sociological data and indicated that a trial court ought to consider whether enforcement would be contrary to the public interest. More specifically, he stated that "The trial court should . . . . be directed to make findings as to the housing facilities available in the district occupied by the colored population and to determine whether there is a need for additional housing that would justify an expansion of the district by absorption of the restricted area." I5I P. 2d 260, 269.

On the other'hand, in Stone v. Jones, I52 P. 2d I8, 22 (Cal. App., I944), affirming the en- 
even those which contain without more a fleeting statement that enforcement violates no public policy,,$^{8}$ need not be considered controlling. In such northern states as have civil rights laws ${ }^{49}$ prohibiting the segregation of the races, even in public places, where physical contact is much closer than is usual between neighbors, the argument is available that enforcement of restrictive covenants contravenes the public policy of the state as expressed in such laws..$^{\circ}$

The question remains whether the decision of a state court, enforcing anti-Negro restrictive covenants by injunction, in a fact situation such as has been described, raises questions under the Fourteenth. Amendment.

forcement of a restrictive covenant, the reaction of the court to apparently similar arguments was that "Collateral possiblities or indirect consequences are beside the issue. Changes, or the" likelihood thereof, incident to the growth of a community, may create or forecast perplexing social problems, but such problems, from the very nature of things, cannot be solved by the courts in the process of litigation of a purely private nature. Any attempt to do so would be an unwarranted interference with the functions of other branches of the government already equipped with power and means for the comprehensive consideration of such problems." Similar language appears in Burkhardt v. Lofton, 146 P. $2 d$ 720, 724-5 (Cal. App., I944).

${ }^{48}$ Koehler v. Rowland, 275 Mo. 573, 205 S.W. 217 (I9r8); Ridgway v. Cockburn, I63 Misc. 5 r r, 296 N.Y.S. 936 (I937); Chandler v. Ziegler, 88 Colo. I, 29 I Pac. 822 (I930); Parmalee v. Morris, 218 Mich. 625, I88 N.W. 330 (r922); Lyons v. Wallen, I33 P. $2 d 555$ (Okla.,. I942).

In Illinois, the only judicial discussion of the constitutional and policy questions is on its face a dictum: "Appellants have not contended that the restrictions violate any of the amendments to the United States constitution, nor that they are against public policy-but complainant has seen fit to argue, at some length, that the restrictions do not violate the fifth, thirteenth or fourteenth amendments to the United States constitution and that they are not against public policy. While it is entirely unnecessary, because of appellants' attitude, for us to consider this argument, we may state that the following authorities cited in support of it sustain the position of complainant: [citing cases]. In spite of the instant argument of complainant, appellants have not seen fit to file a reply brief." Burke v. Kleiman, 277 Ill. App. 5I9, 533-4 (r934).

Moreover even this dictum was based on the briefs in what was later found to be a collusive law suit, which was brought, apparently, for the purpose of establishing this very point among others. See Hansberry v. Lee, 3 xx U.S. 32, 38, 61 S. Ct. II5, Ix7, 85 L. Ed. 22, 25-6 (1940), reversing Lee v. Hansberry, 372 III. 369,24 N.E. $2 d 37$ (1939). These cases were concerned only with the effect of the judgment in Burke v. Kleiman and did not discuss the constitutionality of restrictive covenants.

${ }_{49}$ E.g., L. I885 p. 64, IIl. Rev. Stat. $\$$ I25-8 (Bar Assn. Ed. I943).

5o This analogy was rejected, however, in Burkhardt v. Lofton, I46 P. ad 720 (Cal. App., x944), where, apparently, it was strongly (but unsuccessfully) urged that the public policy of the state had changed, subsequent to the early decisions, to such an extent that restrictive covenants should not have been enforced.

H. B. 563,63 d Gen. Assembly of III. (r943) provided for the invalidation of provisions in deeds, leases, and similar documents which prohibited occupancy or ownership of real estate on grounds of race or color. The bill was tabled, as were similar bills submitted to the 6rst and 62d General Assembly, and S. B. 28I, 62d Gen. Assembly of Ill. (I94I), which provided for the amendment of the Housing Authorities Act to prohibit racial segregation in public housing. For the apparently serious suggestion that legislation invalidating anti-Negro restrictions may be unconstitutional see Illinois Inter-racial Commission, Research Memorandum No. 6, Restrictive Covenants, II-I4 (mimeographed publication, I944). 
Buchanan v. Warley ${ }^{5 \mathrm{x}}$ and the cases which followed it ${ }^{52}$ established in the Supreme Court that legislation restricting the right of a member of a particular race to live on particular land denies rights guaranteed by the Fourteenth Amendment. Chicago, Burlington and Quincy Railroad Co. v. Chicago, ${ }^{53}$ is authority that judicially established rules are subject to the same constitutional limitations as those established by the legislature. Judicial enforcement by injunction of restrictive covenants, where, as in the ordinary case, the covenants have been systematically imposed over a large area, achieves precisely the same purpose as a zoning ordinance prohibiting Negroes from settling in the area. ${ }^{54}$ In either case, the power of government is exercised directly on the individual, and on a discriminatory basis. Hence it is arguable that, for constitutional purposes, judicial enforcement of restrictive covenants is state action which should not be permitted where legislation to the same effect would be invalid. ${ }^{55}$ It should be relevant, moreover, that, as has been indicated, the denial by judicial decree of the right freely to settle in the community is not simply of academic concern, but is fraught with the gravest of practical consequences, in that it dooms the Negro to utilization of housing situated in relatively constricted areas and of a type which would not otherwise be acceptable.

Smith v. Allwright ${ }^{56}$ indicates an inclination, in the Supreme Court, to recognize as state action activities formerly deemed to be only of private concern. The case overruled Grovey v. Townsend, ${ }^{57}$ which had held that the action of the Democratic party of Texas, excluding Negroes from membership, was not state action and hence did not deprive Negroes of rights guaranteed by the Fourteenth Amendment. Instead, the Court at its last term held that, in view of the relationship of the primaries to the whole electoral process, the delegation to the party, by the state, of the power so to fix membership qualifications as to exclude Negroes, made the subsequent act of the party, excluding Negroes, the act of the state. Con-

$5 \times 245$ U.S. 60, 38 S. Ct. 16, 62 L. Ed. 149 (I9I7).

52 Harmon v. Tyler, 273 U.S. 668, 47 S. Ct. 47I, 7 I L. Ed. 83I (I927); Richmond v. Deans, 28I U.S. 704, 50 S. Ct. 407, 74 L. Ed. II 28 (I930).

${ }_{53}$ I66 U.S. 226, I7 S. Ct. 58I, 4I L. Ed. 979 (1897).

${ }_{54}$ The public law element in restrictive covenants is more apparent when it is realized that the so-called contract is enforced in the teeth of the owner of the present interest in the land.

ss On the issue whether injunctions enforcing covenants are unconstitutional governmental action, the language of Corrigan v. Buckley is dictum on its face, the Court having stated that the issue was not properly before it.

${ }^{56}{ }_{321}$ U.S. 649,64 S. Ct. 757,88 L. Ed. 70 (I944).

57295 U.S. 45, 55 S. Ct. 622, 79 L. Ed. I 292 (1935). 
sequently the discrimination was prohibited by the Fourteenth Amendment. Exclusion of Negroes had been accomplished by resolution adopted by the state convention of the party, and it is significant that no legislation of Texas was relied on as having authorized such a resolution. Recognition by the common law of the state of a right so to exclude was suffcient to constitute the resulting exclusion the act of the state. In the opinion the Court emphasized that the importance of the right to vote was a large factor in its decision. It is difficult to assume that the elementary right to live in a community would be deemed of less importance.

During the current term, the Supreme Court has again considered the validity of so-called private action discriminating against Negroes. Steele v. Louisville \& Nashville Railroad $\mathrm{Co}_{0}{ }^{8}$ was a suit brought by a Negro railroad employee to enjoin the enforcement of an agreement between a union and the employer, which agreement discriminated against colored employees. The Railway Labor Act ${ }^{59}$ made the union the exclusive collective bargaining representative for the craft of which the plaintiff was a member. The constitutional argument was that the act was unconstitutional, if, having given a union exclusive bargaining rights, it permitted the union so to use them as to discriminate against Negroes. The Court indicated that if the statute were so construed, serious constitutional questions would arise. These were avoided by construing the act to require the union to bargain in a non-discriminatory manner, for the whole craft, including even such members of the craft as were non-members of the union. This construction was adopted despite the absence of any statutory provisions specifically regulating the manner in which the union was to perform its duties. In a concurring opinion, Mr. Justice Murphy made it clear that he was willing to accept the Court's construction, because the act would otherwise be invalid. It should be noted that, in this case, the relationship of the governmental action, i.e., the legislation, to the discrimination was far less direct than in the ordinary restrictive covenant case. In the labor cases, though the unions exercise powers conferred by legislation, ${ }^{60}$ the final discriminatory exercise of such powers is their own act. In the restrictive covenant cases, the "private" discrimination is ineffectual, in every contested case, until the judicial agency of the government implements it by injunction.

It may be significant that lower courts have cited Corrigan v. Buckley

${ }^{8} 65$ S. Ct. 226,89 L. Ed. (I944).

5948 Stat. II85, 45 U.S.C. $\S$ I51.

${ }^{60}$ However, unions have often achieved the status of exclusive bargaining representatives even independent of legislative aid. 
and used the language of private action to justify refusal of relief against discriminatory action by labor unions, in cases somewhat similar to that just discussed. ${ }^{6 x}$ Clearly the authority of these lower court cases has now been shaken. Another indication of the direction of decision may be that Mr. Justice Rutledge, while still a member of the Court of Appeals for the District of Columbia, took occasion to indicate doubts as to the validity of restrictive covenants. ${ }^{62}$ It is believed that the result of recent decisions has been so to undermine the dictum ${ }^{63}$ for which Corrigan v. Buckley is usually cited, as to raise a question whether the language of that case continues to express the law.

It is contemplated that, with the conclusion of the present war, new construction will relieve present large-scale inadequacies in urban housing. New houses will be built in areas vacant at present, to be occupied by persons whose financial resources are proportionable to construction costs. At the same time still-useful housing will be released for occupancy by groups which are financially less able and which at present endure substandard conditions. This process will entail adjustments in the composition of particular communities, which adjustments can be, on the whole, socially beneficial. However, restrictive covenants, if they continue to be enforced by courts, will, in many communities, deny to Negroes the opportunity to secure a share either in the new construction or in the older and still-useful properties. Although the burden of the restriction will fall with the greatest weight on Negro would-be purchasers and tenants, it will be felt as well by property-owners whose market will be thus restricted and whose cost of obsolescence will thereby be artificially increased. Judicial failure to abandon a rule so costly in its social consequences to the community at large will ultimately require legislative correction, unless abominable housing conditions for Negroes, and the pernicious effects of such conditions on the general community, are to be accepted as a permanent condition of American life.

6x E.g., National Federation of Railway Workers v. National Mediation Board, rro F. 2d 529 (C.A.D.C., r940) cert. den. 3 Io U.S. 628, 60 S. Ct. 975, 84 L. Ed. r399 (I940); James v. International Brotherhood of Boiler Makers, Iron Ship Builders and Helpers of America, 54 F. Supp. 94 (Cal., r944).

${ }^{62}$ Hundley v. Gorewitz, 132 F. 2d 23 (C.A.D.C., I942), was a suit for an injunction to enforce an ordinary restrictive covenant. The "changed conditions" rule was applied to deny relief. The cryptic concurring opinion of Rutledge, J., is reproduced: "I concur in the result for the reason that if such a covenant as is involved in this case is valid in any circunstances, as to which I express no opinion, it is not valid or enforceable in the conditions shown on the present record and stated in the opinion of the court." 132 F. 2 d 23, 25 (italics added).

${ }_{63}$ Note 55 , supra. 